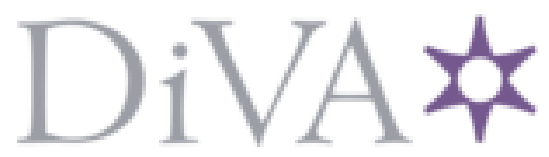

http://www.diva-portal.org

This is the published version of a paper published in Taxon.

Citation for the original published paper (version of record):

Jørgensen, P., Otálora, M., Wedin, M. (2013)

(2235) Proposal to conserve the name Leptogium (lichenized Ascomycota) with a conserved type..

Taxon, 62: 1333-1334

http://dx.doi.org/DOI: 10.12705/626.23

Access to the published version may require subscription.

N.B. When citing this work, cite the original published paper.

Permanent link to this version:

http://urn.kb.se/resolve?urn=urn:nbn:se:nrm:diva-183 


\title{
(2235) Proposal to conserve the name Leptogium (lichenized Ascomycota) with a conserved type
}

\author{
Per M. Jørgensen, ${ }^{1}$ Monica Otalora ${ }^{2} \&$ Mats Wedin ${ }^{2}$ \\ 1 Museum of Natural History, University of Bergen, Allégt. 41, Box 7800, 5020 Bergen, Norway \\ 2 The Swedish Museum of Natural History, Box 5007, 10405 Stockholm, Sweden \\ Author of correspondence: Per M. Jørgensen, per.jorgensen@um.uib.no
}

DOI: http://dx.doi.org/10.12705/626.23

(2235) Leptogium (Ach.) Gray, Nat. Arr. Brit. Pl. 1: 400. 1821 (Collema [unranked] Leptogium Ach., Lichenogr. Universalis: 654. 1810), nom. cons. prop.

Typus: Leptogium azureum (Sw.) Mont. (Collema azureum Sw.), typ. cons. prop.

It has long been known that the generic limit between the lichen genera Collema F.H. Wigg and Leptogium (Ach.) Gray, which has been based mainly on cortex anatomy, is artificial (see, e.g., Degelius in Symb. Bot. Ups. 12(3). 1954). Only recently in several molecular works (see Otalora \& al. in Fungal Diversity, in press, DOI http:// dx.doi.org/10.1007/s13225-013-0266-1) has it become possible to untangle this complex group of collemataceous genera. It is now quite clear that Leptogium as typified by Clements \& Shear (in Gen. Fung.: 317. 1931) by "Leptogium lacerum (Sw.) Gray" (i.e., L. lacerum Gray, nom illeg. $=$ L. lichenoides $(\mathrm{L}$.) Zahlbr, but see Jørgensen in Taxon 58: 1002-1003. 2009) is a genus of small-squamulose species. It comprises only about forty species. The bulk of the species usually referred to Leptogium, close to a hundred larger foliose ones, must change their name to Mallotium (Ach.) Gray. Both Leptogium and Mallotium were established as subdivisions of Collema by Acharius (1.c. 1810), the latter comprising species with hairy lower surfaces. Mallotium has ever since been used in that sense, though most often at sectional level, though even that use has been challenged, e.g., by Jørgensen (in Herzogia 3: 433-460. 1975). It would be most unfortunate now to take this name up for the whole genus, and it would require more than fifty new combinations. We therefore propose that Leptogium be conserved with a new type, the widespread Leptogium azureum (Sw.) Mont., a central, non-hairy species included in this subdivision of Collema by Acharius, to avoid this major nomenclatural instability. This will keep most species in Leptogium, while the smaller, squamulose species would need a new generic name, for which Scytinium (Ach.) Gray, Nat. Arr. Brit. Pl. 1: 398. 1821 ('Scytenium') (based on Collema [unranked] Scytinium Ach., Lichenogr. Universalis: 642. 1810) is available. As it has been typified (Stafleu in Regnum Veg. 102: 1594. 1969) on Scytinium palmatum (Huds.) Gray, the only species of the original three treated by Acharius that Gray knew from The British Isles. Gray gives no explanation for his 
use of the orthographic variant "Scytenium", rather than Acharius's original (a misprint?). We prefer the original spelling to which Gray's variant is correctable.

Should this proposal fail, a great number of the large, widespread, none-hairy species (more than fifty) will have to change to
Mallotium, a name which, since its publication by Acharius, about 200 years ago, solely has been connected to the hairy species (on sectional level). The application of Mallotium for all these species will be a most confusing factor in the stabilization of the new taxonomy and nomenclature. 